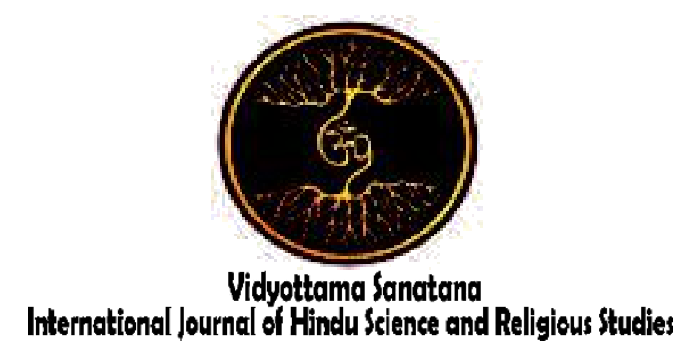

Vol. V No. 1 June 2021

\title{
MATERUNA NYOMAN INFORMAL EDUCATION IN DEVELOPING TERUNA CHARACTER IN TENGANAN PEGRINGSINGAN, KARANGASEM
}

\author{
By: \\ I Nengah Juliawan ${ }^{1}$, A.A Pt. Suari ${ }^{2}$ \\ STAHN Mpu Kuturan Singaraja \\ E-mail: ${ }^{1}$ CamebinkJulian@Gmail.com, ${ }^{2}$ agung.suari@gmail.com
}

\begin{tabular}{|l|l|l|}
\hline Received: December 10, 2021 & Accepted: Juni 30, 2021 & Published: June 30, 2021 \\
\hline
\end{tabular}

\begin{abstract}
Education is an effort to produce quality of human resources. Formal and informal education are away of cultural inheritance to the younger generations therefore their cultural traditions can survive and develop in the midst of Indonesian society. One of the traditions that live in Bali with traditional education system is the Materuna Nyoman tradition. The Materuna Nyoman tradition is a series of ceremonies that has the aim of changing the status of teenage stage to adults stage according to custom. During the procession of a series of ceremonies is rich of meaningful education that form the character of adolescents into personal and responsible characters. Materuna Nyoman tradition needs to be educated to young leaners in Tenganan Pegringsingan to determine changes in the character of adolescents in Materuna Nyoman's education. This study was a qualitative research with an ethnographic research approach. Data was collected using the observation method, interview method, literature method. Collected data was analyzed using the interpretive descriptive analysis method. The analysis was carried out during and after data collection. With the activity steps to reduce data, present data, and carry out verification to make conclusions. The results showed that: (1) the process of the Nyoman Materuna series, namely Maajak-ajakan, Melali, Basen Pamit, Padewaraan or kagedong, Matamiang, Malegar, Ngintarang Katekung, Namiu Katamiu, Ngejot Gede, Ngetog, Katinggah. The characters formed in the participants of Materuna Nyoman are responsible for themselves and the village environment.
\end{abstract}

Keywords: Materuna Nyoman Tradition, Education, Character. 


\section{INTRODUCTION}

Character education is predicted to be a style of education for the Indonesian nation, but currently its implementation has only reached the theoretical realm, while the real form of character education has not been fully found in the teaching and learning process in the classroom. At the theoretical level, character education is very promising to solve the problems of education in Indonesia. However, it deviates at the practical level. According to Qurais Shihab $(1996 ; 321)$ the society's value system has affected the attitudes and perspectives of society as a whole. If their value system and views are limited to the present moment, then their efforts and ambitions are limited to the same thing. The implementation of the education process is also an effort to produce quality and highly competitive human resources for competition in the era of globalization. Education, both formal and informal, is a medium of cultural inheritance to young generations so that their cultural traditions can survive and develop in the midst of Indonesian society. As an island where the majority of the population is Hindu, Bali is known to have various uniqueness and great cultural values in the practice of religion. It is dominated by various forms of yadnya ceremonies.

Balinese culture at this time is the result of a culture that undergoes a continuous process in the form of preservation, filtering, processing, compilation and acceptance and development of various cultural systems, ranging from native culture, Hindu culture, to national and global cultures that cannot be separated from the principles of moral values.

Regarding culture and religion, Balinese people have various traditions. Each region in Bali has its own distinct traditions in carrying out their ceremonies. "Every place has a ceremony procedure which is carried out in accordance with the general rules and opinions or loka dresta (desa kala patra dan mawacara)” (Karda, 2007:43 dalam
Manuaba, 2011:1). Bali life community has organizations that work in the field of life specifically called sekaa. One of them is a group or a forum for social organizations for the development of young people who grow and develop on the basis of social awareness and responsibility from the community (sekaa teruna), especially the younger generations. Similar to other villages in Bali, Tenganan Pegringsingan Traditional Village also has a community organization in the form of a group or sekaa.

As the people of Bali Aga, Tenganan Pegringsingan has a distinctive style and identity compared to Balinese people in general. The difference is in the customs and traditions that are still well preserved and adhere to the customary law or awig-awig adat. There are various customary traditions in the Tenganan Pegringsingan which are interesting to study. One of them is the tradition of Materuna Nyoman as a forum for character building education specifically for young men in the Tenganan Pegringsingan. Materuna Nyoman tradition is one of the life cycle ceremonies carried out by teenagers in the Tenganan Pegringsingan. It provides deep meaning of character educations that make Hindu youth more religious. Materuna Nyoman can be analogized to the butterfly metamorphosis (from a caterpillar to a cocoon to a beautiful flying butterfly) with Hindu character as the foundation in living life as adults. This tradition lasts for a year with three phases or phases. All the participants have to pass the whole phases. Each phase in Materuna Nyoman is marked by a ritual or activity that aims to improve the quality of the participants'character.

The tradition of Materuna Nyoman is important to be explored because this tradition is an informal character building education process which all younger people in the Tenganan Pegringsingan have to pass it. Hopefully, there are several things that can be adopted or developed by the national education system in implementing character 
education at schools or other educational institutions in Indonesia.

\section{METHOD}

Sudarmayanti (2002: 25) states that methodology is systematic steps to gain knowledge, while methods are procedures or ways of knowing something with these systematic steps. Methods serve to simplify problems, making them easier to solve and understand. The approach of this study is a qualitative approach with characteristics. In the context of a qualitative approach, the main elements as the content of the research design in education are generally the research context (problem background); the focus of the study or the subject matter to be researched, the research objectives, the scope and setting of the research (the natural background of the study), the theoretical perspective (social phenomena) and literature review, and the method used by the ethnographic method by recording any data obtained from the field.

Ethnographic research design is also a qualitative research procedure that describes, analyzes, and interprets the behavioral patterns, beliefs, and shared language of a group of cultures that develop over time. In this study, the researcher observed in depth the Tradition of Materuna Nyoman in the Tenganan Pegringsingan Community. Unlike the usual types of qualitative research, data is analyzed after completing field data collection, ethnographic research data is analyzed in the field according to the context or situation that occurred at the time the data was collected, it is intended that researchers can compare the attitudes of traditional participants and the dynamics of character that occur in forming character education values.

\section{RESULT AND DISCUSSION}

There are no inscriptions that reveal the historical origins of Tenganan Pegeringsingan village, because in $1841 \mathrm{AD}$ ) or 1763 (Isaka) the local village experienced a fire which burned all village documents in 1842 . The awig-awig which is currently used as a legal basis for the regulations in Tenganan Pegeringsingan community was rewritten from the memories of the villager as an authorized version of the Klungkung king and the Karangasem king. However, to find out the origin of the traditional village of Tenganan Pengringsingan, several mythological stories that are still vaguely still exist in the Tenganan community in particular, as well as the Balinese in general.

According to Goris (via Runa, 2007: 19) states that the name Tenganan has been ancient since its existence. This is evidenced by the mention of the name of the village in a Balinese inscription with the name Tranganan, then later in its development it became Tenganan village which is commonly known today by Balinese people in general.

The tradition of Materuna Nyoman has been carried out hereditary by the people in Tenganan Pegringsingan. Materuna Nyoman is implemented because of this tradition is mandatory for every child who is a teenager, in the phase of change to become a legal adult by custom. The background to the implementation of the Materuna Nyoman tradition is the awareness of the ancestors of the Tenganan Pegringsingan community about the importance of the meaning of education for children who will be the next generations of Krama Desa. It is about how to form responsible characters from an early age, to be responsible for themselves and their responsibilities to their village. When a person is getting married, before he carries out Materuna Nyoman, the marriage is not legalized by the village, being subject to Elad (sanction) or an offense.

Materuna Nyoman consists of two syllables namely Materuna and Nyoman. The meaning of Materuna in general Balinese language is childhood phase becomes adulthood phase. The word Nyoman when interpreted generally in Bali is the naming of a child whose order is for the third child. Contrary to the meaning of Nyoman in 
Tenganan Pegringsingan, especially in the tradition of Materuna Nyoman, the word Nyoman has nothing to do with the third child, because all the participants who took Materuna Nyoman were not only the third child. The word Nyoman is just a term from the traditional village of Tenganan pegringsingan.

The process of Materuna Nyoman is carried out for a year according to the customary calendar system of the Tenganan Pegringsingan. Materuna Nyoman is one of the requirements by the traditional village. This process starts from the full moon of the third Balinese month (sasih kaulu) until the next full moon of sasih kaulu which is named nemu gelang. However, this tradition cannot be implemented every year and the intervals in its implementation are different. Some processes are lasted up to four years or seven seven years. This is because participants from Materuna Nyoman are required to have representatives from each patemu-patemu in the Tenganan Pegringsingan, such as: Patemu Kelod, Patemu Tengah and Patemu Kaja.

\section{First Phase (Early Phase)}

\section{a. Maajak-ajakan}

Maajak-ajakan is the earliest and mandatory phase for all the participants before doing the Materuna Nyoman. Maajak-ajakan means inviting or gathering which aims aims to gather children who are ready and old enough to carry out the Materuna Nyoman tradition. Maajakajakan process is usually carried out a year or two year ahead before the Materuna Nyoman is held because the parents have to provide the financial support. Maajak-ajakan is family ceremony that is carried out at each participant in turns. In this phase, people discuss about a good time for carrying out Materuna Nyoman ceremony. Parents who their son(s) will do Materuna Nyoman held a banquet for the entire community in
Tenganan without exception. They were gathered together in a megibung (eating together) event. The parents ask for blessings and prayers to their son(s) when participate in Materuna Nyoman. The next procession will be held at Bale Patemu Teruna for matuturan (talk) with the term Nyekolang (occupied), and on the way to Bale Patemu which is in accordance with the origin of Patemu's father. The candidates of Materuna Nyoman will be carried by his father, starting from the front of Bale Patemu until Bale Patemu. This carrying process indicates that a father is bringing his son to become an adult customly.

On Bale Patemu, the participant of Materuna Nyoman will do matuturan process with Keliang Teruna. After the matuturan, the partcipants come down from Bale Patemu without being carried by their father. This process indicated that the participants had been recognized as a customary adult through the Materuna Nyoman process.

\section{b. Melali}

Melali is the next important steps after meajak-ajakan process in Materuna Nyoman. Melali can be interpreted as taking a walk, but in its meaning in the Materuna Nyoman process, is a process of tapa semadhi and pray throughout twenty temples in the area of Tenganan Pegringsingan.

This activity is carried out every three days during Beteng nights (Balinese calendar system). The melali process is carried out at midnight (at exactly 12 p.m.). Participants have to come to twenty temples without being escorted by anyone. Before entering each temple, the participants should clean themselves both physically and spiritually. The pupose of this process to make their mind becomes calm and positive aura. The participants are not to 
go through the door when entering the temples. They have to jump to the wall or fence of the temples. The entering process is known as miyasa or ngemaling. This process purposely done in the middle of the night and it is invisible for the villagers because at this time the participants is kepingit or being secret. This process is carried out continuously until the last temple.

When this melali procession is carried out by the participants, at the same time they will do an election for Jro Mekel, namely the leader of the participants Materuna Nyoman. Jro Mekel is chosen by a family whose children follow the process of Materuna Nyoman and Prajuru Adat. Being a Jro Mekel, he has a duty like a teacher in a formal school. Jro Mekel who will later provide learning materials about knowledge of the village area, customs, culture and ceremonial activities found in the Traditional Village of Tenganan Pegringsingan apart from this, Jro Mekel also has the function of changing the character of the participants in order to become a better person by disciplining the participants and developing good ethics for the participants of Materuna Nyoman.

\section{Second Phase (Main Phase)}

\section{a. Basen Pamit Ceremony}

Basen Pamit is a ceremony carried out which is carried out on the full moon sasih kaulu (the third Balinese month) by the participants of Materuna Nyoman. The participants bring offering such as base buah (betel fruit) to Pura Puseh and they should not be accompanied by anyone. All the participants have to do the ceremony only once at night even they are ill. The participant considered to have failed if he is hospitalized and to be kesebelan/cuntaka (grieving). $\mathrm{He}$ is allowed to participate on the next
Materuna Nyoman period. During the process, the participants pray at the temple in aim of Nyatiang Dewek (selfassured) and ask for blessing to Ida Sang Hyang Widhi Wasa.

Basen Pamit indicates that informal educational process of Materuna Nyoman has begun. All participants are obliged to be stay in dormitory Jro Mekel's house. They have to follow the rules from Jro Mekel without exception. This obligation greatly influences the discipline training and forms the character of the participants to become better and more responsible individuals.

\section{b. Padewasan/Kagedong}

Kagedong is analogized to a cocoon of butterfly, which cannot be seen by anyone, including their parents. This process makes the participants to be kepingit (being secret). The word kagedong comes from the word gedong or a house built from bedeg (a type of woven bamboo). This bedeg was made by teruna bani and teruna pengawin who were seniors of the participants. The bedeg was arranged in a rectangular shape without a roof and floor equipped with sanan (bamboo which functions as a supporting tool for carrying).

Kagedong or Padewasan ceremony is started by the participants shaving off their hair and metatah. The aims of shaving off their hair is to make Materuna Nyoman participants feel the same togetherness among other participants, no one is differentiated by class or family status. The process is followed by self-purification neither physically or spiritually. The process of purification is known as Masigsig Ambuh. Once gedong is ready, the participants enter into it without being seen by their parents.

The participants of Materuna Nyoman are given a Base Buel (rolled betel leaf) to put in the mouth, but could 
not be eaten or chewed, only bitten and could not fall. This process makes the participants cannot speak and hold back all his words. The purpose of bitting the base buel is the participants of Materuna Nyoman should think first then to be wise before speaking. After entering the gedong, the gedong is carried only by the Pengawin Teruna (senior one level higher than the participants or Teruna Nyoman) while the Teruna Bani (Penegenan Base) carries the means of ceremonial equipment in the form of base (betel), buah (betel fruit), uyah (salt) and various kinds of fruit and snacks that are put together and then carried on sugarcane stalks. Kagedong ceremony starts from Jro Mekel's dormitory to Subak / Gantih Daha. The process continues to Gatih Nengah, Gantih Nyoman and Gatih Daha Wayah. Arriving at Gantih Daha Wayah, the Teruna Nyoman sat in the northern part of Bale Buga and Daha Wayah sat in the south without seeing their face each other. There is something that block between them in Bale Buga.

Keliang Daha Wayah gives offering to Penegenan Base. During kagedong procession at Gantih Daha, there is a ritual namely Masabat Endut. Endut (mud) is made from a mixture of endut with buffalo dung (Jro Gede Ombo). The endut and buffalo dung have to be taken from Tenganan Pegringsingan village. Only Pengawin Teruna who has family relationship with the Daha Gantih Wayah is allowed to make the mixture of endut. This process symbolize the courage of Teruna Nyoman. In the beginning, the process of Masabatan Endut is Masamodana. Masamodana is carried out by Teruna Bani. Teruna Bani pray to the sesuhunan to begin Mesut Endut. Once Teruna Bani recites the Samodana, Teruna Pengawin throw endut to Daha Ganti Wayah at the same time. Teruna Pengawin who does not have family relationship to Daha Ganti Wayah is allowed to throw the endut to Daha Ganti Wayah. During the process of throwing the endut, daha (girl) is not allowed to dodge, be angry or speak rudely (swearing). Daha is only allowed to cover themselves with a cloth up to the head without covering his face. There are some rules in throwing endut. Teruna Pengawin throws endut is like throwing a stone. Throwing endut is done continuously until Teruna Bani finishes reciting the Samodana (mantra).

Kagedong and Mesabat Endut are carried out in each of Gantih Daha. The first was Gantih Wayah, and then the Nyoman Teruna participants continued their journey to Gantih Nengah. They do the same procession as in Gantih Wayah. Mesabat Endut in Gantih Nengah is quite different from Gantih Wayah. Daha who is thrown endut diffeernt according to the Gantih where Daha from. The process is repeated when Nyoman Teruna arrive at Gantih Nyoman. Kagedong ceremony continues until three times in each Gantih Daha for every three days. It is carried out every Tri Wara Beteng calendar system (according to the calendar system of the Tenganan Pegringsingan Traditional Village).

\section{c. Matamiang}

The word Matamiang comes from word tamiang which means shield or self-protection. Tamiang (shield) is made from Ate weaving by people in Tenganan Pegringsingan. Matamiang is performed by the participants of Teruna Nyoman a few days before death moon of sasih keulu on beteng day. Matamiang can be directly analogized to the phase of butterfly from cocoon to become butterflies. The participants cover their chests with Tamiang and 
visit each Gantih Daha accompanied by Jro Mekel and Penegenan Base to give offering to each Daha. Matamiang ceremony will be held on each Gantih Daha. The participants of Teruna Nyoman sit on Bale Buga and watch the ceremony therefore the participants learn about the ceremonial procedures and know the meaning of the ceremony. Matamiang ceremony is meant to fortify ourselves from negative influences and remind us of our own weakness. It is necessary for participants to learn how to be a stronger person in leading as adults.

\section{d. Malegar}

Malegar is the final procession in the main phase of Materuna Nyoman. It is held right on death moon of sasih kaulu (the third Balinese month). Malegar means that being detached or people can see the participants' activities. Teruna Nyoman participants are close to the final phase of the main phase in Meteruna Nyoman procession. The cocoon turns to a butterfly. The participants do not need to hide from anyone. People now can see their activities. During Malegar process, Jro Mekel shows to the participants of Materuna Nyoman parts of village therefore they surely know parts of their village and boundaries. By knowing their territory, Teruna Nyoman can protect his area from outside influences who try to take over his village area. During this process, participants also visit each of the Gantih Daha's to show them to Daha that they are ready to step forward the next phase.

Malegar has a high philosophical value. A life cycle is very important for the life journey of every human being because humans will experience physical and spiritual growth both in sekala and niskala as well as transitional periods in the phases of life. As young generations, who are lack of experiences, should get various knowledge therefore they become 'beautiful butterfly' that are both knowledgeable for their life and societies.

\section{Third Phase (Final Phase)}

The final phase is the phase carried out by the participant Materuna Nyoman to legalize himself as a Teruna Nyoman. After going through various kinds of ceremonies in Materuna Nyoman, the final phase in this procession arrived which took place from sasih kesanga (the ninth Balinese month) to sasih kaulu (the third Balinese month).

\section{a. Ngintarang Ketekung}

Ngintarang Katengkung means to walk around the hill. The participants bring equipment such as traditional weapons, namely Tulupan. All Teruna Nyoman brings tulupan to protect themselves and their territory in the event of dangerous threats from outside the village. Teruna Nyoman should continue to be able to learn, in understanding themselves and their territory by interacting with others and the nature. During this process, Truna Nyoman is accompanied by Daha. Daha is in charge of providing and preparing food for Teruna Nyoman such as Katipat (ketupat), chicken meat, and processed from nuts. This activity is known as Ngejot Katipat. Ngejot Katipat is a symbol of gratitude from the Daha, as well as a reward for giving Teruna Nyoman to Daha during the last Kagedong ceremony. Daha and Teruna Nyoman enjoy the food together.

\section{b. Namiu Katamiu}

Namiu Katamiu is a form of gratitude procession for Teruna Nyoman participants because part of the Materuna Nyoman process series has been going well and smoothly. Namiu Katamiu is held on sasih kedasa (the tenth Balinese month) according to 
Tenganan Pegringsingan calendar system. People who take part in Materuna Nyoman procession included Jro Mekel, Penegenan Base, Teruna Bani and Teruna Pengawin come and join the procession. This procession is taken place at Jro Mekel's house or Truna Nyoman's dormitory. Teruna Nyoman participants and people invited to Namiu Katamiu procession will enjoy the dishes prepared by the Nyoman Teruna participants by eating together, namely Megibung.

During the ceremony, Teruna Nyoman are divided according to their respective Bale Patem origins. First day, Namiu Katamiu is held by Teruna Nyoman participants from Bale Patemu Kelod. The next day, Namiu Katamiu is continued by Teruna Nyoman participants from Nyoman Bale Patemu Tengah. Last Namiu Katami is held by Teruna Nyoman from Bale Patemu Kaja. This ceremony has the meaning of teaching the Teruna Nyoman participants who are in accordance with their Bale Patemanya to be a responsible person. It is expected that the participants when finishing the Materuna Nyoman procession, they return to Bale Patemunya and participated in the organization as a new member called Teruna Nyoman.

\section{c. Ngejot Gede}

Ngejot Gede ceremony is similar to Namiu Katamiu ceremony. The ceremony is held on sasih jiyesta/ desta (the eleventh Balinese month). Ngejot Gede is a symbol of gratitude to Daha, by giving various kinds of processed food to each of Gantih Daha who has helped a lot with the Materuna Nyoman procession. Teruna Nyoman walked toward to each of the Gantih Daha and give food that made of pork/chicken, such as satay, pigs rolled (babi guling) and various kinds of traditional cakes. Ngejot Gede procession only between
Truna Nyoman participants and Daha. This procession teaches Truna Nyoman participants about how harmonious relationship is created, in the future, they understand the importance of women's roles in life and also respect women as part of his life.

\section{d. Ngetog}

Ngetog is a series procession from Materuna Nyoman which held by Teruna Nyoman participants and accompanied by Jro Mekel. The participants come to each of the Gantih Daha every morning on the Tri Wara Beteng calendar (once every three days) right before the village kulkul is sounded around 04.30 until 05.00 in the morning. During the process, Teruna Nyoman participants left the dormitory and then walk towards each of Gantih Daha. Start from Gantih Wayah, continued to Gantih Nengah and finally to Gantih Nyoman. At Gantih Jro Mekel would knock on Gantih Daha's door then reciting the Samodana. Teruna Nyoman participants only stand behind Jro Mekel and watch Jro Mekel doing Masamodana. Teruna Nyoman participants are not allowed to precede Jero Mekel when walking. It means that Teruna Nyoman participants should respect their leader. This Ngetog procession will last until sasih kaulu (the third Balinese month) which means Teruna Nyoman will complete the Materuna Nyoman procession.

\section{e. Katinggal}

Katinggal is the final procession of Materuna Nyoman. At this procession, Taruna Nyoman is analogized a butterfly that has been perfect with its strong wings and ready to fly. Katinggal is carried out on sasih kaulu on the calendar system of the Tenganan Pegringsingan Traditional Village. Katinggal procession ends the one year education period of all Teruna Nyoman participants. They have 
received a lot of education about knowledge of traditional villages, socio-culture, village areas and many more lessons that they get.

The beginning of the Katinggal procession, the Teruna Nyoman participants gathere at the dormitory. They wear special costume, namely Payas Gede of Tenganan Pegringsingan. Teruna Nyoman wear udeng (headband) with gold flower ornaments, kamen covered with Saput Gringsing (Tenganan Pegringsingan cloth) and carry a keris weapon called Kadutan. They have completed the study when they come to Katinggal phase. However, an important part of Katinggal procession is the messages (advice) from Jro Mekel to the Teruna Nyoman participants. Jro Mekel will hide and Teruna Nyoman participants have to find Jro Mekel's hiding place so Jro Mekel can deliver the message.

The main phase of the Katinggal procession is a wise message from Jro Mekel. In Gantih Daha, the Teruna Nyoman participants will sit face-toface to Jro Mekel at Bale Buga. Teruna Bani and Teruna Pengawin reciting Samodana (sacred mantra) which indicates the Materuna Nyoman procession will end on that day run smoothly. The procession is followed by giving the last wise message by Jro Mekel. The wise message reminds Teruna Nyoman of all the lessons during the procession. Here is the wise message from Jro Mekel to Teruna Nyoman participants:

"Cai Teruna Nyoman ajak mekejang, jani suba madan atiban genep cai malajahang dewek, da nyen cai engsap lan suud malajah, anak nu liu plajahaane ane lakar cai plajahin disisi,

\begin{abstract}
pejalan cai ne enu lantang ento ngeranayang de kanti cai med malajain dewek, nah jani cai ajak makejang suba seken ane madan Teruna Nyoman".
\end{abstract}

Translation:

"Teruna Nyoman, it has been a year since you learned about life and enrich the knowledge. Do not forget about everything that you have learned nor give up learning. There are still many things that you will learn in the future, out of your life here. You have long live journey and do not stop to gain knowledge. Well, right from now, all of you officially become Materuna Nyoman."

o Mekel Rangik on interview 10 July 2020)

The procession of Materuna Nyoman ended by closing message from Jro Mekel. All the participants of Materuna Nyoman have been legally become membership of Teruna Nyoman in each Bale Patemu. Teruna Nyoman will begin to participate in every activity Teruna organization. All the lessons that they have learned during the Materuna Nyoman procession will be applied later in every traditional activities.

\section{CONCLUSION}

The tradition of Materuna Nyoman has been carried out hereditary by the people in Tenganan Pegringsingan. Materuna Nyoman process lasts a year according to Tenganan Pegringsingan calendar system. Materuna Nyoman processions educate the teenages (esp. boys) to learn about character education also ethical and knowledge about the nature of life as a human. The ancestors of the Tenganan Pegringsingan have an awareness 
of the importance of an education for their descendants who will live their future adult life. The goal in implementing Materuna Nyoman is to mature knowledge about customs in the village.

The participants have been prepared to become Krama Desa. They learn how to be able carrying out obligation as Tenganan Pegringsingan people. They should know how to do the obligation according to AwigAwig of the Tenganan Pegringsingan. There some parts during Materuna Nyoman procession, such as: Maajak-ajakan, Melali, Basen Pamit, Padewasaan atau kagedong, Matamiang, Malegar, Ngintarang Katekung, Namiu Katamiu, Ngejot Gede, Ngetog, Katinggal. The process of Materuna Nyoman gives a significant impact on young characters. It is obtained through a long and meaningful process. Through this process, it is hoped that the Teruna Nyoman will have better personalities and character.

\section{REFERENCES}

Agus, I Putu Ananta Wijaya Sari. 2009. Upacara Teruna Nyoman terhadap pendewasaan anak di Desa Pakraman Tenganan Pegringsingan, Kecamatan Manggis, Kabupaten Karangasem ditinjau dari Sudut Pandang Pendidikan Agama Hindu. Skripsi IHDN Denpasar. Tidak diterbitkan.
Arikunto, S.2000. Prosedur Penelitian,: Suatu Pendekatan Praktis, Yogyakarta: Rineka Cipta.

Atmaja, dkk.2010.Etika Hindu. Surabaya : Paramita.

Awig-awig Desa Adat Tenganan Pegringsingan.

Gandhi, Teguh, 2011. Filsafat Pendidikan. Yogyakarta :AR-RUZZ Media.

Moleong, Lexy.J. 2013. Metedologi Penelitian Kualitatif Edisi Revisi. Bandung: Remaja Rosdakarya.

Ngurah, I Gusti Made, dkk. 2006. Buku Penelitian Agama Hindu Untuk Perguruan Tinggi. Surabaya : Paramita.

Nyoman, Ida Bagus Adi Putra Manuaba, 2011. Tradisi Ritual Materuna Nyoman Di Desa Adat Tenganan Pegeringsingan Kecamatan Manggis Kabupaten Karangasem. Skripsi STKIP Amplapura. Tidak diterbitkkan.

Parisada Hindu Dharma Indonesia Pusat, 2000. Seminar Kesatuan Tafsir Terhadap Aspek-aspek Agama Hindu.PHDI-XV.

Widia, Mangku, Tim Penyusun. 2005. Profile 8 Desa Terpilih.

Yasa, I Wayan.2015. Notes of Tenganan Pegeringsingan. 